\title{
Acute and Chronic Toxicities of Pandanus Amaryllifolius Roxb. Water Extract from the Roots in Rats
}

\author{
Seewaboon Sireeratawong, Natthakarn Chiranthanut ${ }^{1}$, Nirush Lertprasertsuke ${ }^{3}$, Kanjana \\ Jaijoy $^{4}$ \\ ${ }^{1}$ Department of Pharmacology, Faculty of Medicine, Chiang Mai University, Chiang Mai 50200, Thailand. \\ ${ }^{2}$ Division of Pharmacology, Department of Preclinical Science, Faculty of Medicine, Thammasat University, Pathum Thani 12120, Thailand. \\ ${ }^{3}$ Department of Pathology, Faculty of Medicine, Chiang Mai University, Chiang Mai 50200, Thailand. \\ ${ }^{4}$ McCormick Faculty of Nursing, Payap University, Chiang Mai 50000, Thailand.
}

Received: August 22, 2016; Accepted: September 3, 2016; Published: September 15, 2016

*Corresponding author: Seewaboon Sireeratawong, Department of Pharmacology, Faculty of Medicine, Chiang Mai University, Chiang Mai 50200, Thailand. Tel: +66944793695; Email: seewaboon@gmail.com

\begin{abstract}
Pandanus amaryllifolius Roxb. is one of the most valuable herbs that has been used as a medicine for diabetes mellitus. The study of the acute toxicity of the plant extract was conducted in male and female rats by a single oral administration of the test substance at a dose of $5 \mathrm{~g} / \mathrm{kg}$ body weight. The toxic sign, general behaviors, mortality, and microanatomical characteristics of internal organs were examined at the end of experiment. The results showed no sign of differences as compared to the normal control rat. Thus a single oral administration of $5 \mathrm{~g} / \mathrm{kg}$ body weight does of $P$. amaryllifolius extract significantly cause no toxicity. For the chronic toxicity test, after an oral feeding both male and female rats daily with the extract $1,2,4$ and $8 \mathrm{~g} / \mathrm{kg}$ body weight for 180 days, toxic signs, animal behavior and health monitoring were then investigated. There were no abnormalities in the test groups as compared to the controls. Furthermore, the rats of the test and control groups on day 180 and the satellite group on day 208 were analyzed by measuring their final body and organ weights, taking necropsy, and examining hematology, blood clinical chemistry, and microanatomy. Results did not show any differences except an increase in the body weight of the treated male rats when compared with the control groups. These results combined with the information of signs, behavior and health monitoring can lead to a conclusion that an oral administration of $P$. amaryllifolius extract at the doses of 1, 2, 4 and $8 \mathrm{~g} / \mathrm{kg}$ body weight for 180 days does not produce chronic toxicity.
\end{abstract}

Keywords: Acute toxicity; Chronic toxicity; Pandanus ammaryllifolius Roxb

\section{Introduction}

Pandanus amaryllifolius Roxb. (Synonym P. odorus Ridl; Thai name: Toei-hom, family Pandanaceae) has been abundantly cultivated in Thailand. The leaves of $P$. amaryllifoliuscan are used as spice, food coloring and flavoring agents in culinary application. Root of $P$. amaryllifolius has long been reported as a remedy for diabetes mellitus. The ethanol extract from the leaf of $P$. amaryllifolius shows the antidiabetic effect on streptozotocininduced diabetic mice [1]. The water extract of $P$. odorus root shows the hypoglycemic effect in diabetic rats [2-3]. In an acute toxicity study, $50 \%$ of lethal dose $\left(\mathrm{LD}_{50}\right)$ after intraperitoneal injection of the water extract from the root of $P$. odoruswas $1.87 \mathrm{~g} /$ $\mathrm{kg}$ in male and female rats and $1.62 \mathrm{~g} / \mathrm{kg}$ in male and female mice. The $\mathrm{LD}_{50}$ after oral administration was over $8 \mathrm{~g} / \mathrm{kg}$ in both sexes of rat and mice [4]. However, the long term oral administration of the water extract from the root of $P$. amarylifolius has never been evaluated.

The present study aimed to assess the adverse effects related to different doses in order to find the acceptable safety level of the water extract from the root of $P$. amarylifolius in rats by determining both oral acute and chronic toxicities in rat.

\section{Methods \\ Plant material}

The root of P. amaryllifolius was collected from Chachoengsao province in Thailand. The plant materials were identified and the voucher specimen (QBG 24869) was deposited at Queen Sirikit Botanic Garden, The Botanical Garden Organization, Ministry of Natural Resources and Environment, Mae Rim, Chiang Mai, Thailand.

\section{Preparation of the extract}

Roots of $P$. amaryllifolius were washed in running water, then dried and ground to a powder. The extract was prepared as follows: the powder (1 kg) was suspended in distilled water (14 L) and the mixture was boiled for 3-4 hours followed by the filtration. The residue from the filtration was boiled and filtered again with the same procedure. The filtrates were collected and evaporated in a rotary evaporator. The weight and percentage yield of the crude extract were recorded. The $P$. amaryllifolius water extract was stored at $4-5^{\circ} \mathrm{C}$ after preparation.

\section{Experimental animals}

Male and female Sprague-Dawley rats (120-130 g) were obtained from the National Laboratory Animal Center, Nakorn Pathom, Thailand. All animals were kept in the room maintained 
under environmentally controlled conditions of $25 \pm 1^{\circ} \mathrm{C}$ and $12 \mathrm{~h}$ light-12 h dark cycle. Before each experiment, the animals were fasted overnight with free access to water. All experimental protocols were approved by the Animal Ethics Committee of Faculty of Medicine, Thammasat University (No. 0002/2005).

\section{Acute toxicity study}

The acute oral toxicity was evaluated in rats as described by the Organization of Economic Co-operation and Development (OECD) Guideline for Testing of Chemicals [5] and World Health Organization (WHO) Guideline [6]. The female rats were divided into two groups of ten animals $(n=5)$. The control group received a vehicle in a volume of $1 \mathrm{ml} / \mathrm{kg}$ body weight. The $P$. amaryllifolius extract was orally administered to rats using a single dose of $5 \mathrm{~g} /$ $\mathrm{kg}$ body weight. The animals were monitored for appearance of signs of toxicity immediately after dosing and at 1, 2, 4, and $6 \mathrm{~h}$ after dosing. Observations were focused on changes in skin, fur, eyes, mucous membranes, respiratory and circulatory systems, autonomic and central nervous systems as well as somatomotor activity and behavioral pattern. The number of survivors were noted after $24 \mathrm{~h}$ and then maintained for a further 14 days with a once daily observation. The animals that died within this period were necropsies. Animals were weighed on day 0 , and on days $7^{\text {th }}$ and $14^{\text {th }}$. At the end of the experiment, all surviving animals were sacrificed with pentobarbital sodium. The vital organs including heart, lungs, livers, kidneys, spleen, adrenals, sex organs and brain were subjected to gross and histology examination.

\section{Chronic toxicity study}

The method was conducted according to the OECD Guideline for Testing of Chemicals [7] and WHO Guideline [6]. Briefly, P. amaryllifolius extract at the doses of $1,2,4$ and $8 \mathrm{~g} / \mathrm{kg}$ body weight were administered to rats (ten males, ten females) once daily over 180 days, the control group received the vehicle. The satellite group (ten males, ten females) was given the extract at the dose of $8 \mathrm{~g} / \mathrm{kg}$ body weight over 180 days and kept for other 28 days after the treatment in order to detect a delayed occurrence of toxic effect.

All rats were observed for appearance of signs of toxicity or behavioral alterations during the experimental period. At the end of each experiment, the rats were fasted 12 hours, and then anesthetized with ether. Their blood was collected from a common carotid artery for hematological study, using Sysmex K-1000 Fully Automated Hematology Analyzer. The serum was separated from the blood and measured levels of glucose, blood urea nitrogen (BUN), creatinine, total protein, albumin, total bilirubin, direct bilirubin, alkaline phosphatase (ALP), serum glutamic-oxaloacetic transaminase (SGOT), and serum glutamicpyruvic transaminase (SGPT), using the COBAS INTEGRA System.

After the blood collection, the animals were immediately sacrificed for tissue studies. The following tissues and organs were weighted, grossly examined, and then fixed in $10 \%$ buffered formaldehyde solution: heart, lungs, thymus, livers, kidneys, spleen, adrenals, small intestine, stomach and duodenum, muscle with sciatic nerve, thoracic spines, brain, eyes, sex organs, uterus and epididymis. The fixed organs from all animals were examined by histological method.

\section{Statistical analysis}

Results were expressed as mean \pm standard error of mean (S.E.M.). Statistical significance was determined by one-way analysis of variance (ANOVA) and post hoc least-significant difference (LSD) test. The data obtained from acute toxicity studies were analyzed using Student's $t$-test. $P$ values less than 0.05 were considered significant.

\section{Results and Discussions}

The acute toxicity study aims to investigate animal responses after a single dose administration of $P$. amaryllifolius extract. The results of this study provided early information for safety evaluation and then appropriate dosage for further chronic toxicity assessment. Signs and symptoms of indicated organ systems, body weight, organ weight and histological data were collected and analyzed to investigate the acute toxicity of this extract.

The result of our study found that all rats did not exhibit signs of toxicity or mortality after a single oral administration of P. amaryllifolius extract at the dose of $5 \mathrm{~g} / \mathrm{kg}$. The body weight gain and internal organ weights were observed since a decrease in both parameters would indicate the presence of toxicity. The body weight on the $7^{\text {th }}$ and $14^{\text {th }}$ day of female rats received the extract did not different from that of the control group Table 1. At the end of this study, the average weight of the internal organs and condition of the color and the texture were normal and comparable to the control group Table 2. In addition, the histological examination of the lung, heart, liver, spleen, adrenal grand, kidney, thymus, stomach and duodenum, small intestinal,

Table 1: Body weights of female rats in acute toxicity of the water extract from the root of P. amaryllifolius.

\begin{tabular}{|l|l|l|l|}
\hline \multirow{2}{*}{} & \multicolumn{3}{l|}{ Body weight (g) } \\
\cline { 2 - 4 } & Day 0 & Day $\mathbf{7}^{\text {th }}$ & Day $\mathbf{1 4}^{\text {th }}$ \\
\hline $\begin{array}{l}\text { Control } \\
\text { 5. amaryllifolius }\end{array}$ & $121.80 \pm 3.06$ & $157.00 \pm 4.31$ & $178.30 \pm 4.87$ \\
\hline Vag & $119.80 \pm 1.82$ & $151.60 \pm 2.41$ & $176.80 \pm 2.83$ \\
\hline
\end{tabular}

Values are expressed as mean \pm S.E.M., $\mathrm{n}=5$.

Table 2: Organ weights of female rats in acute toxicity of the water extract from the root of P. amaryllifolius.

\begin{tabular}{|l|l|l|}
\hline \multicolumn{3}{|l|}{ Organ weights $\mathbf{( g )}$} \\
\hline Female & Control & P. amaryllifolius $\mathbf{5 g} / \mathbf{k g}$ \\
\hline Lung & $0.99 \pm 0.03$ & $0.96 \pm 0.03$ \\
\hline Heart & $0.75 \pm 0.02$ & $0.75 \pm 0.05$ \\
\hline Liver & $6.61 \pm 0.31$ & $6.54 \pm 0.21$ \\
\hline Spleen & $0.58 \pm 0.02$ & $0.59 \pm 0.01$ \\
\hline Adrenal & $0.03 \pm 0.00$ & $0.03 \pm 0.00$ \\
\hline Kidney & $0.79 \pm 0.01$ & $0.85 \pm 0.03$ \\
\hline Ovary & $0.07 \pm 0.00$ & $0.06 \pm 0.00$ \\
\hline Values are expressed as mean \pm S.E.M., $\mathrm{n}=5$. \\
\hline
\end{tabular}


ovary, uterus, muscle and nerve, thoracic spine, eyes and brain were normal in both the control and the treated groups. Furthermore, the histological examinations in both control and treated groups revealed normal results of these following organs: the lung, heart, liver, spleen, adrenal grand, kidney, thymus, stomach and duodenum, small intestinal, ovary, uterus, muscle and nerve, thoracic spine, eyes and brain. As shown in Fig.1, as compared to the control, no abnormality was found in vital organs, liver and lung of rats after receiving the extract. According to the OECD guideline for testing of chemicals (2001) [5], the results of acute toxicity suggested that $P$. amaryllifolius extract is reasonably nontoxic.

Because signs, symptoms, organ weight and body weight become a preliminary evidence for evaluation of sample's acute toxicity, the initial assessment of chronic toxicity was similarly undertaken. After administration of P.amaryllifolius, we observed the signs and symptoms of indicated organ systems, and weighted the body and organs before examining the histological outcomes. Results of the chronic toxicity showed that administration of the extract at doses of 1, 2, 4 and $8 \mathrm{~g} / \mathrm{kg}$ daily over 180 days does not cause mortality and behavioral changes. In female treated rats, the body weight and internal organ weight were not different from those of the control group Table 3-4. The body weight of male rats was found to be statistically different from that of the control group Table 5. However, the weights of some internal organs of male rats were found to be statistically different from those of the control group Table 6. On the other hands, the gloss examinations did not show any abnormality of animal tissues in all groups and in both sexes. Thus, these results may be due to variation of the size and/or weight of animals' organs [8].

Taken the above results together, it could be concluded that $P$. amaryllifolius extract had no chronic toxicity on animals. To confirm these findings, the histology examination of all animal organs was determined whether or not the toxicity of $P$. amaryllifolius was present.

Hematologic data were useful for diagnosis and investigation of initial abnormality to demonstrate healthy status of animals

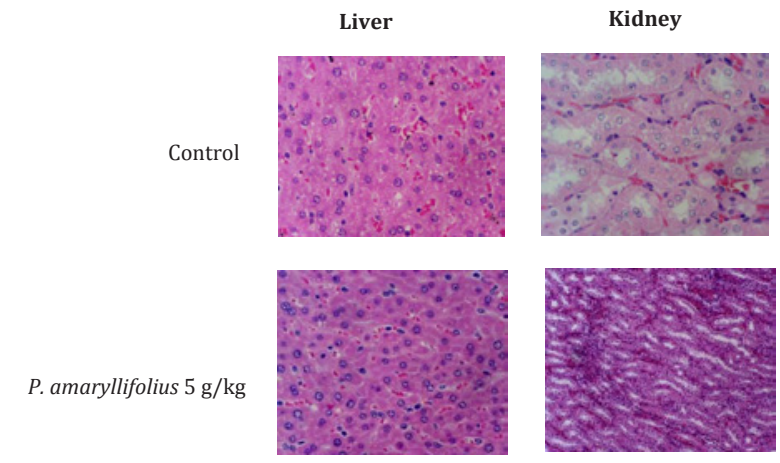

Figure 1: Histology of female kidney and liver in control and P. amaryllifoliustreated groups in acute toxicity. Section was stained with haematoxylin and eosin. No significant damage was detected in any treatment group.

\begin{tabular}{|c|c|c|c|}
\hline \multicolumn{4}{|c|}{$\begin{array}{l}\text { Table 3: Body weights of female rats in chronic toxicity of the water } \\
\text { extract from the root of P. amaryllifolius. }\end{array}$} \\
\hline & \multicolumn{3}{|c|}{ Body weight (g) } \\
\hline & Day 0 & Day $90^{\text {th }}$ & $\begin{array}{lrr}D & \text { a } & y \\
180^{\text {th }} & \end{array}$ \\
\hline Control & $121.80 \pm 1.38$ & $261.00 \pm 4.91$ & $\begin{array}{l}291.20 \pm \\
6.82\end{array}$ \\
\hline \multicolumn{4}{|l|}{ P.amaryllifolius } \\
\hline $1 \mathrm{~g} / \mathrm{kg}$ & $125.60 \pm 2.53$ & $274.50 \pm 6.34$ & $\begin{array}{l}297.40 \pm \\
7.06\end{array}$ \\
\hline $2 \mathrm{~g} / \mathrm{kg}$ & $121.00 \pm 2.15$ & $260.60 \pm 7.58$ & $\begin{array}{l}281.60 \pm \\
4.78\end{array}$ \\
\hline $4 \mathrm{~g} / \mathrm{kg}$ & $120.60 \pm 1.96$ & $267.40 \pm 5.07$ & $\begin{array}{l}294.00 \pm \\
5.57\end{array}$ \\
\hline $\begin{array}{l}8 \mathrm{~g} / \mathrm{kg} \\
\text { Satellite group }\end{array}$ & $\begin{array}{l}122.20 \pm 3.05 \\
126.60 \pm 4.08\end{array}$ & $\begin{array}{l}266.60 \pm 5.01 \\
251.60 \pm 6.83\end{array}$ & $\begin{array}{l}286.80 \pm \\
4.38 \\
285.60 \pm \\
9.47\end{array}$ \\
\hline \multicolumn{4}{|c|}{$\begin{array}{l}\text { Values are expressed as mean } \pm \text { S.E.M., } \mathrm{n}=10 \text {. } \\
\text { A satellite group was given the P. amaryllifolius extracting at } 8 \mathrm{~g} / \mathrm{kg} \\
\text { daily over } 180 \text { days followed by no treatment for } 28 \text { days. }\end{array}$} \\
\hline
\end{tabular}

Table 4: Organ weights of female rats in chronic toxicity of the water extract from the root of P. amaryllifolius.

\begin{tabular}{|c|c|c|c|c|c|c|}
\hline & \multirow[t]{2}{*}{ Control } & \multicolumn{4}{|c|}{ P. amaryllifolius } & \multirow[b]{2}{*}{$\begin{array}{l}\text { Satellite } \\
\text { group }\end{array}$} \\
\hline & & $1 \mathrm{~g} / \mathrm{kg}$ & $2 \mathrm{~g} / \mathrm{kg}$ & $4 \mathrm{~g} / \mathrm{kg}$ & $8 \mathrm{~g} / \mathrm{kg}$ & \\
\hline Lung & $\begin{array}{l}1.54 \pm \\
0.10\end{array}$ & $\begin{array}{l}1.47 \pm \\
0.03\end{array}$ & $\begin{array}{l}1.42 \pm \\
0.03\end{array}$ & $\begin{array}{l}1.55 \pm \\
0.05\end{array}$ & $\begin{array}{l}1.49 \pm \\
0.04\end{array}$ & $1.41 \pm 0.04$ \\
\hline Heart & $\begin{array}{l}1.18 \pm \\
0.08\end{array}$ & $\begin{array}{l}1.11 \pm \\
0.03\end{array}$ & $\begin{array}{l}1.07 \pm \\
0.04\end{array}$ & $\begin{array}{l}1.11 \pm \\
0.03\end{array}$ & $\begin{array}{l}1.16 \pm \\
0.05\end{array}$ & $1.11 \pm 0.04$ \\
\hline Liver & $\begin{array}{l}6.90 \pm \\
0.19\end{array}$ & $\begin{array}{l}7.43 \pm \\
0.22\end{array}$ & $\begin{array}{l}6.97 \pm \\
0.21\end{array}$ & $\begin{array}{l}7.37 \pm \\
0.24\end{array}$ & $\begin{array}{l}7.15 \pm \\
0.21\end{array}$ & $7.01 \pm 0.22$ \\
\hline Spleen & $\begin{array}{l}0.73 \pm \\
0.04\end{array}$ & $\begin{array}{l}0.76 \pm \\
0.02\end{array}$ & $\begin{array}{l}0.68 \pm \\
0.01\end{array}$ & $\begin{array}{l}0.74 \pm \\
0.02\end{array}$ & $\begin{array}{l}0.72 \pm \\
0.02\end{array}$ & $0.71 \pm 0.02$ \\
\hline Kidney & $\begin{array}{l}0.99 \pm \\
0.07\end{array}$ & $\begin{array}{l}1.04 \pm \\
0.03\end{array}$ & $\begin{array}{l}1.03 \pm \\
0.03\end{array}$ & $\begin{array}{l}1.06 \pm \\
0.02\end{array}$ & $\begin{array}{l}1.07 \pm \\
0.03\end{array}$ & $0.99 \pm 0.02$ \\
\hline Ovary & $\begin{array}{l}0.11 \pm \\
0.00\end{array}$ & $\begin{array}{l}0.12 \pm \\
0.00\end{array}$ & $\begin{array}{l}0.11 \pm \\
0.00\end{array}$ & $\begin{array}{l}0.11 \pm \\
0.00\end{array}$ & $\begin{array}{l}0.11 \pm \\
0.00\end{array}$ & $0.10 \pm 0.00$ \\
\hline
\end{tabular}

Values are expressed as mean \pm S.E.M., $\mathrm{n}=10$.

A satellite group was given the P. amaryllifolius extracting at $8 \mathrm{~g} / \mathrm{kg}$ daily over 180 days followed by no treatment for 28 days.

Table 5: Body weights of male rats in chronic toxicity of the water extract from the root of P. amaryllifolius.

\begin{tabular}{|c|c|c|c|}
\hline \multicolumn{4}{|c|}{ Body weight (g) } \\
\hline & Day 0 & Day $90^{\text {th }}$ & Day $180^{\text {th }}$ \\
\hline Control & $129.60 \pm 2.59$ & $432.20 \pm 11.96$ & $479.20 \pm 13.75$ \\
\hline \multicolumn{4}{|l|}{ P.amaryllifolius } \\
\hline 1g/kg & $129.60 \pm 2.82$ & $425.60 \pm 7.60$ & \\
\hline $2 \mathrm{~g} / \mathrm{kg}$ & $124.00 \pm 1.36$ & $413.60 \pm 10.16$ & $436.80 \pm 10.16^{*}$ \\
\hline $4 \mathrm{~g} / \mathrm{kg}$ & $124.00 \pm 1.36$ & $418.20 \pm 7.58$ & $428.80 \pm 13.25^{*}$ \\
\hline $8 \mathrm{~g} / \mathrm{kg}$ & $129.20 \pm 3.04$ & $415.60 \pm 11.75$ & $448.40 \pm 12.84$ \\
\hline Satellite group & $124.40 \pm 2.43$ & $411.60 \pm 10.50$ & $475.00 \pm 9.91$ \\
\hline
\end{tabular}


and risks of any disease. Hematological parameters provide vital information regarding the status of bone marrow activity and intravascular effects such as anemia or hemolysis. The lower level of WBC is likely caused by some immune diseases, viral infections or hematologic diseases such as a plastic anemia or bone marrow suppression, which resulting in the decrease of $\mathrm{RBC}$, platelets and WBC. In addition, leukemia could be one of the factors leading to normal or reduced WBC known as a leukemic leukemia. However, the bacterial infection usually results in WBC to increase dramatically which requires a differential count of WBC to establish diagnosis. Moreover, high numbers of WBC could represent leukemia, but white blood cells were needed to be considered thoroughly. Some of the hematological values of female and male rats were slightly different from those of the control group Table 7-8 whereas the differential white blood cells count values showed no difference between the control and the treated groups Table 9-10. However, the slight change in all of the parameters is not much significant because variations of the animals must be taken into account [9-11]. Therefore, the results indicated that $P$. amaryllifolius did not cause chronic toxicity on either blood cells or the hematopoietic production that causes abnormalities on animals.

The liver, kidney and pancreas are major vital organs. The liver plays a role in synthesis and delivery of various compounds, especially glucose, protein and lipid to be utilized in the body. While essential vitamins and minerals are accumulated in the liver, hepatotoxic chemicals or metals are kept before being excreted out of the body. One of the kidneys' main functions is to produce and control hormone synthesis, in particular hormones related to calcium and erythrocyte production. These hormones are able to collect nourishing substances which are being reabsorbed by renal tubules. Additionally, apart from excretion of wasted products, the kidney can control the balance of fluids and electrolytes.

The clinical blood chemistry values were used to analyze kidney function (BUN and creatinine) and liver function (glucose, total protein, albumin, total and direct bilirubin, SGOT, SGPT and ALP). In both female and male satellite groups, some clinical blood chemistry values such as creatinine, BUN, SGOT and ALP were statistically different from those of the control group. In general, if the clinical blood chemistry values differ more or less than one fold from the normal values, abnormality of kidney, liver and pancreas's function should be noted [11-15]. However, in our study, the observed difference was less than one fold Table 11-12, suggesting normal function of the organs. The results can be concluded that $P$. amaryllifolius extract had no chronic toxicity on liver and kidney.

Thehistological examination of cells and tissues is an important procedure in chronic toxicity evaluation. Although there were no significant changes in the following parameters: symptoms, body weight, organ weight, gloss examination, hematology and blood chemistry profiles; the histological examination pointed out that cells and tissues of the animals significant altered from baselines after administration of $P$. amaryllifolius. In this study, the histological features of the lung, heart, spleen, adrenal grand, thymus, stomach and duodenum, small intestinal, ovary, uterus,

Table 6: Organ weights of male rats in chronic toxicity of the water extract from the root of P. amaryllifolius.

\begin{tabular}{|c|c|c|c|c|c|c|}
\hline & \multirow[t]{2}{*}{ Control } & \multicolumn{5}{|c|}{ P. amaryllifolius } \\
\hline & & $1 \mathrm{~g} / \mathrm{kg}$ & $2 \mathrm{~g} / \mathrm{kg}$ & $4 \mathrm{~g} / \mathrm{kg}$ & $8 \mathrm{~g} / \mathrm{kg}$ & Satellite group \\
\hline Lung & $1.77 \pm 0.04$ & $1.81 \pm 0.04$ & $1.78 \pm 0.08$ & $1.69 \pm 0.03$ & $1.72 \pm 0.04$ & $1.71 \pm 0.03$ \\
\hline Heart & $1.63 \pm 0.05$ & $1.58 \pm 0.05$ & $1.51 \pm 0.03$ & $1.46 \pm 0.04^{*}$ & $1.53 \pm 0.04$ & $1.59 \pm 0.05$ \\
\hline Liver & $11.44 \pm 0.27$ & $11.68 \pm 0.41$ & $11.13 \pm 0.42$ & $11.04 \pm 0.36$ & $11.51 \pm 0.50$ & $11.91 \pm 0.28$ \\
\hline Spleen & $0.94 \pm 0.04$ & $0.92 \pm 0.04$ & $0.88 \pm 0.03$ & $0.85 \pm 0.04$ & $0.92 \pm 0.03$ & $0.94 \pm 0.02$ \\
\hline Kidney & $1.48 \pm 0.02$ & $1.57 \pm 0.03^{*}$ & $1.40 \pm 0.02 *$ & $1.41 \pm 0.03$ & $1.43 \pm 0.04$ & $1.42 \pm 0.03$ \\
\hline Testis & $1.89 \pm 0.10$ & $2.13 \pm 0.04^{*}$ & $2.17 \pm 0.02^{*}$ & $2.04 \pm 0.06$ & $2.15 \pm 0.03^{*}$ & $2.12 \pm 0.05^{*}$ \\
\hline
\end{tabular}

Values are expressed as mean \pm S.E.M., $\mathrm{n}=10$.

A satellite group was given the $P$. amaryllifolius extracting at $8 \mathrm{~g} / \mathrm{kg}$ daily over 180 days followed by no treatment for 28 days.

* Significantly different from control, $p<0.05$.

Table 7: Hematological values of female rats in chronic toxicity of the water extract from the root of P. amaryllifolius.

\begin{tabular}{|l|l|l|l|l|l|l|}
\hline & Control & P.amaryllifolius & \multicolumn{3}{l|}{} \\
\hline & & $\mathbf{1 g} / \mathbf{k g}$ & $\mathbf{2 g} / \mathbf{k g}$ & $\mathbf{4 g} / \mathbf{k g}$ & $\mathbf{8 g} / \mathbf{k g}$ & Satellite group \\
\hline RBC $(\mathbf{x 1 0} / \mathbf{\mu l})$ & $7.57 \pm 0.11$ & $7.39 \pm 0.25$ & $7.25 \pm 0.13$ & $7.07 \pm 0.11^{*}$ & $7.22 \pm 0.12$ & $7.29 \pm 0.07$ \\
\hline HGB (g/dl) & $15.20 \pm 0.18$ & $14.92 \pm 0.49$ & $14.67 \pm 0.29$ & $14.48 \pm 0.10$ & $14.68 \pm 0.21$ & $15.03 \pm 0.17$ \\
\hline HCT (\%) & $46.10 \pm 0.58$ & $43.90 \pm 1.44$ & $42.20 \pm 2.39 *$ & $43.40 \pm 0.58$ & $44.10 \pm 0.78$ & $45.90 \pm 0.55$ \\
\hline MCV (fl) & $60.60 \pm 0.30$ & $60.34 \pm 0.37$ & $60.94 \pm 0.24$ & $61.47 \pm 0.42$ & $61.01 \pm 0.41$ & $62.94 \pm 0.43^{*}$ \\
\hline MCH (pg) & $20.08 \pm 0.18$ & $20.20 \pm 0.15$ & $20.23 \pm 0.13$ & $20.50 \pm 0.25$ & $20.32 \pm 0.14$ & $20.61 \pm 0.10^{*}$ \\
\hline MCHC (g/dl) & $33.14 \pm 0.25$ & $33.47 \pm 0.19$ & $33.22 \pm 0.19$ & $33.36 \pm 0.24$ & $33.21 \pm 0.16$ & $32.76 \pm 0.25$ \\
\hline Platelet (x10 $/ \boldsymbol{\mu l )}$ & $6.28 \pm 0.38$ & $6.26 \pm 0.67$ & $6.96 \pm 0.43$ & $6.19 \pm 0.51$ & $7.34 \pm 0.25$ & $6.41 \pm 0.31$ \\
\hline
\end{tabular}

Values are expressed as mean \pm S.E.M., $\mathrm{n}=10$.

A satellite group was given the $P$. amaryllifolius extract at $8 \mathrm{~g} / \mathrm{kg}$ daily over 180 days followed by no treatment for 28 days.

* Significantly different from control, $p<0.05$. 
Table 8: Hematological values of male rats in chronic toxicity of the water extract from the root of P. amaryllifolius

\begin{tabular}{|c|c|c|c|c|c|c|}
\hline & \multirow[t]{2}{*}{ Control } & \multicolumn{5}{|c|}{ P. amaryllifolius } \\
\hline & & $1 \mathrm{~g} / \mathrm{kg}$ & $2 \mathrm{~g} / \mathrm{kg}$ & $4 \mathrm{~g} / \mathrm{kg}$ & $8 g / k g$ & Satellite group \\
\hline $\operatorname{RBC}\left(\times 10^{6} / \mu \mathrm{l}\right)$ & $8.15 \pm 0.09$ & $7.89 \pm 0.15$ & $7.90 \pm 0.16$ & $7.96 \pm 0.18$ & $8.17 \pm 0.11$ & $7.86 \pm 0.12$ \\
\hline HGB (g/dl) & $15.64 \pm 0.14$ & $15.31 \pm 0.28$ & $15.55 \pm 0.15$ & $15.55 \pm 0.27$ & $15.79 \pm 0.13$ & $15.29 \pm 0.19$ \\
\hline HCT (\%) & $47.60 \pm 0.52$ & $46.40 \pm 1.04$ & $46.90 \pm 0.82$ & $47.30 \pm 0.91$ & $48.10 \pm 0.66$ & $46.80 \pm 0.51$ \\
\hline MCV (fl) & $58.42 \pm 0.34$ & $58.73 \pm 0.29$ & $59.20 \pm 0.41$ & $59.28 \pm 0.31$ & $58.76 \pm 0.25$ & $59.40 \pm 0.30^{*}$ \\
\hline MCH (pg) & $19.19 \pm 0.13$ & $19.41 \pm 0.16$ & $19.65 \pm 0.27$ & $19.54 \pm 0.19$ & $19.35 \pm 0.17$ & $19.46 \pm 0.14$ \\
\hline MCHC (g/dl) & $32.84 \pm 0.08$ & $33.06 \pm 0.30$ & $33.22 \pm 0.42$ & $32.87 \pm 0.23$ & $32.93 \pm 0.26$ & $32.76 \pm 0.18$ \\
\hline Platelet $\left(\mathrm{x} 10^{5} / \mu \mathrm{l}\right)$ & $6.48 \pm 0.72$ & $6.78 \pm 0.71$ & $6.85 \pm 0.44$ & $6.78 \pm 0.46$ & $7.22 \pm 0.37$ & $7.99 \pm 0.17^{*}$ \\
\hline
\end{tabular}

Table 9: White blood cell count values of female rats in chronic toxicity of the water extract from the root of P. amaryllifolius

\begin{tabular}{|l|l|l|l|l|l|l|}
\hline & Control & P.amaryllifolius & & \\
\hline & & $\mathbf{1 g} / \mathbf{k g}$ & $\mathbf{2 g} / \mathbf{k g}$ & $\mathbf{4 g} / \mathbf{k g}$ & $\mathbf{8 g} / \mathbf{k g}$ & Satellite group \\
\hline WBC $(\mathbf{x 1 0} / \boldsymbol{\mu l})$ & $2.67 \pm 0.28$ & $2.57 \pm 0.09$ & $2.30 \pm 0.22$ & $2.19 \pm 0.17$ & $2.42 \pm 0.42$ & $2.20 \pm 0.27$ \\
\hline PMN (\%) & $19.30 \pm 2.20$ & $19.90 \pm 5.35$ & $15.70 \pm 2.39$ & $19.80 \pm 3.10$ & $16.00 \pm 2.05$ & $20.50 \pm 2.94$ \\
\hline LYMP (\%) & $72.20 \pm 2.91$ & $71.20 \pm 4.89$ & $76.60 \pm 2.45$ & $72.70 \pm 2.99$ & $75.60 \pm 1.72$ & $71.70 \pm 3.04$ \\
\hline MONO (\%) & $6.10 \pm 1.14$ & $5.60 \pm 0.60$ & $4.40 \pm 0.56$ & $5.00 \pm 0.39$ & $5.20 \pm 0.57$ & $5.10 \pm 0.55$ \\
\hline EOS (\%) & $2.40 \pm 0.50$ & $3.30 \pm 0.88$ & $3.30 \pm 0.67$ & $2.50 \pm 0.64$ & $3.20 \pm 0.66$ & $2.70 \pm 0.52$ \\
\hline BASO (\%) & $0.00 \pm 0.00$ & $0.00 \pm 0.00$ & $0.00 \pm 0.00$ & $0.00 \pm 0.00$ & $0.00 \pm 0.00$ & $0.00 \pm 0.00$ \\
\hline Va) & & & & &
\end{tabular}

Values are expressed as mean \pm S.E.M., $\mathrm{n}=10$.

A satellite group was given the P. amaryllifolius extracting at $8 \mathrm{~g} / \mathrm{kg}$ daily over 180 days followed by no treatment for 28 days.

Table 10: White blood cell count values of male rats in chronic toxicity of the water extract from the root of P. amaryllifolius.

\begin{tabular}{|l|l|l|l|l|l|l|}
\hline & Control & P.amaryllifolius & & \\
\hline & & $\mathbf{1 g} / \mathbf{k g}$ & $\mathbf{2 g} / \mathbf{k g}$ & $\mathbf{4 g} / \mathbf{k g}$ & $\mathbf{8 g} / \mathbf{k g}$ & Satellite group \\
\hline WBC $(\mathbf{x 1 0} / \boldsymbol{\mu l})$ & $3.64 \pm 0.19$ & $3.78 \pm 0.34$ & $3.51 \pm 0.22$ & $3.49 \pm 0.22$ & $3.49 \pm 0.20$ & $3.38 \pm 0.34$ \\
\hline PMN (\%) & $17.70 \pm 2.09$ & $19.60 \pm 2.39$ & $20.60 \pm 1.48$ & $22.70 \pm 3.42$ & $14.70 \pm 1.19$ & $16.10 \pm 0.84$ \\
\hline LYMP (\%) & $72.50 \pm 2.72$ & $72.20 \pm 2.48$ & $70.00 \pm 2.05$ & $68.00 \pm 3.54$ & $77.60 \pm 1.80$ & $76.80 \pm 0.71$ \\
\hline MONO (\%) & $6.10 \pm 1.01$ & $6.00 \pm 0.74$ & $6.00 \pm 0.79$ & $5.70 \pm 0.89$ & $4.20 \pm 0.68$ & $4.90 \pm 0.48$ \\
\hline EOS (\%) & $3.70 \pm 0.91$ & $2.20 \pm 0.44$ & $3.00 \pm 0.61$ & $3.60 \pm 0.82$ & $23.50 \pm 0.54$ & $2.20 \pm 0.36$ \\
\hline BASO (\%) & $0.00 \pm 0.00$ & $0.00 \pm 0.00$ & $0.00 \pm 0.00$ & $0.00 \pm 0.00$ & $0.00 \pm 0.00$ & $0.00 \pm 0.00$ \\
\hline V) & & & & & \\
\hline
\end{tabular}

Values are expressed as mean \pm S.E.M., $\mathrm{n}=10$.

A satellite group was given the P. amaryllifolius extract at $8 \mathrm{~g} / \mathrm{kg}$ daily over 180 days followed by no treatment for 28 days.

Table 11: Clinical blood chemistry values of female rats in chronic toxicity of the water extract from the root of P. amaryllifolius.

\begin{tabular}{|c|c|c|c|c|c|c|}
\hline & \multirow[t]{2}{*}{ Control } & \multicolumn{5}{|c|}{ P. amaryllifolius } \\
\hline & & $1 \mathrm{~g} / \mathrm{kg}$ & $2 \mathrm{~g} / \mathrm{kg}$ & $4 \mathrm{~g} / \mathrm{kg}$ & $8 \mathrm{~g} / \mathrm{kg}$ & Satellite group \\
\hline Glucose (mg/dl) & $104.90 \pm 4.94$ & $101.90 \pm 5.14$ & $97.50 \pm 8.78$ & $95.90 \pm 3.81$ & $97.50 \pm 6.20$ & $116.60 \pm 5.30$ \\
\hline BUN (mg/dl) & $18.90 \pm 0.90$ & $18.30 \pm 1.24$ & $20.10 \pm 1.08$ & $20.20 \pm 0.59$ & $20.00 \pm 1.30$ & $18.20 \pm 0.66$ \\
\hline Creatinine (mg/dl) & $0.34 \pm 0.02$ & $0.30 \pm 0.01$ & $0.35 \pm 0.02$ & $0.33 \pm 0.01$ & $0.40 \pm 0.02^{*}$ & $0.37 \pm 0.02$ \\
\hline Total protein (g/dl) & $5.15 \pm 0.09$ & $4.92 \pm 0.08^{*}$ & $5.13 \pm 0.06$ & $5.19 \pm 0.07$ & $5.35 \pm 0.07$ & $5.43 \pm 0.07^{*}$ \\
\hline $\operatorname{Albumin}(\mathrm{g} / \mathrm{dl})$ & $2.80 \pm 0.07$ & $2.77 \pm 0.05$ & $2.74 \pm 0.05$ & $2.75 \pm 0.05$ & $2.77 \pm 0.06$ & $2.83 \pm 0.06$ \\
\hline Total bilirubin (mg/dl) & $0.12 \pm 0.01$ & $0.18 \pm 0.06$ & $0.11 \pm 0.01$ & $0.10 \pm 0.00$ & $0.12 \pm 0.02$ & $0.15 \pm 0.03$ \\
\hline Direct bilirubin (mg/dl) & $0.05 \pm 0.03$ & $0.10 \pm 0.07$ & $0.01 \pm 0.01$ & $0.01 \pm 0.01$ & $0.03 \pm 0.02$ & $0.13 \pm 0.04$ \\
\hline SGOT $(\mathbf{U} / \mathbf{l})$ & $145.00 \pm 13.32$ & $153.20 \pm 26.75$ & $116.20 \pm 6.41$ & $131.00 \pm 8.56$ & $185.90 \pm 26.49$ & $171.00 \pm 12.23$ \\
\hline SGPT (U/I) & $49.00 \pm 8.48$ & $48.20 \pm 5.24$ & $37.70 \pm 1.28$ & $44.40 \pm 5.35$ & $51.30 \pm 9.44$ & $44.20 \pm 5.99$ \\
\hline $\operatorname{ALP}(\mathbf{U} / \mathbf{l})$ & $33.40 \pm 1.33$ & $39.20 \pm 4.45$ & $44.30 \pm 2.92^{*}$ & $38.20 \pm 2.01$ & $42.30 \pm 2.76^{*}$ & $34.90 \pm 1.90$ \\
\hline
\end{tabular}


Table 12: Clinical blood chemistry values of male rats in chronic toxicity of the water extract from the root of P. amaryllifolius.

\begin{tabular}{|c|c|c|c|c|c|c|}
\hline & \multirow[t]{2}{*}{ Control } & \multicolumn{5}{|c|}{ P. amaryllifolius } \\
\hline & & $1 \mathrm{~g} / \mathrm{kg}$ & $2 \mathrm{~g} / \mathrm{kg}$ & $4 \mathrm{~g} / \mathrm{kg}$ & $8 g / k g$ & Satellite group \\
\hline Glucose (mg/dl) & $117.30 \pm 5.90$ & $111.40 \pm 7.65$ & $113.70 \pm 5.48$ & $114.20 \pm 5.61$ & $116.20 \pm 5.44$ & $118.40 \pm 2.81$ \\
\hline BUN (mg/dl) & $19.20 \pm 0.70$ & $22.20 \pm 0.89^{*}$ & $23.50 \pm 0.87^{*}$ & $22.30 \pm 0.84^{*}$ & $20.90 \pm 0.86$ & $19.20 \pm 0.44$ \\
\hline Creatinine (mg/dl) & $0.29 \pm 0.02$ & $0.30 \pm 0.01$ & $0.32 \pm 0.01$ & $0.31 \pm 0.02$ & $0.29 \pm 0.01$ & $0.36 \pm 0.02^{*}$ \\
\hline Total protein (g/dl) & $4.90 \pm 0.05$ & $5.00 \pm 0.08$ & $4.86 \pm 0.05$ & $4.96 \pm 0.07$ & $5.07 \pm 0.08$ & $5.34 \pm 0.08^{*}$ \\
\hline $\operatorname{Albumin}(\mathrm{g} / \mathrm{dl})$ & $2.65 \pm 0.04$ & $2.63 \pm 0.04$ & $2.52 \pm 0.04^{*}$ & $2.51 \pm 0.03^{*}$ & $2.58 \pm 0.04$ & $2.79 \pm 0.06^{*}$ \\
\hline Total bilirubin (mg/dl) & $0.10 \pm 0.00$ & $0.12 \pm 0.02$ & $0.14 \pm 0.04$ & $0.12 \pm 0.02$ & $0.10 \pm 0.00$ & $0.14 \pm 0.02$ \\
\hline Direct bilirubin (mg/dl) & $0.00 \pm 0.00$ & $0.00 \pm 0.00$ & $0.05 \pm 0.05$ & $0.03 \pm 0.03$ & $0.00 \pm 0.00$ & $0.08 \pm 0.03^{*}$ \\
\hline SGOT $(U / \mathbf{l})$ & $120.80 \pm 14.62$ & $135.20 \pm 17.76$ & $111.20 \pm 7.60$ & $122.30 \pm 10.44$ & $102.50 \pm 7.56$ & $180.00 \pm 15.66^{*}$ \\
\hline SGPT (U/l) & $46.70 \pm 4.91$ & $44.70 \pm 3.32$ & $47.50 \pm 4.31$ & $43.30 \pm 3.60$ & $44.80 \pm 4.78$ & $42.60 \pm 2.67$ \\
\hline $\operatorname{ALP}(\mathbf{U} / \mathbf{l})$ & $53.10 \pm 2.86$ & $60.10 \pm 3.07$ & $71.20 \pm 6.22 *$ & $63.20 \pm 4.40$ & $66.20 \pm 7.35$ & $54.10 \pm 1.49$ \\
\hline
\end{tabular}

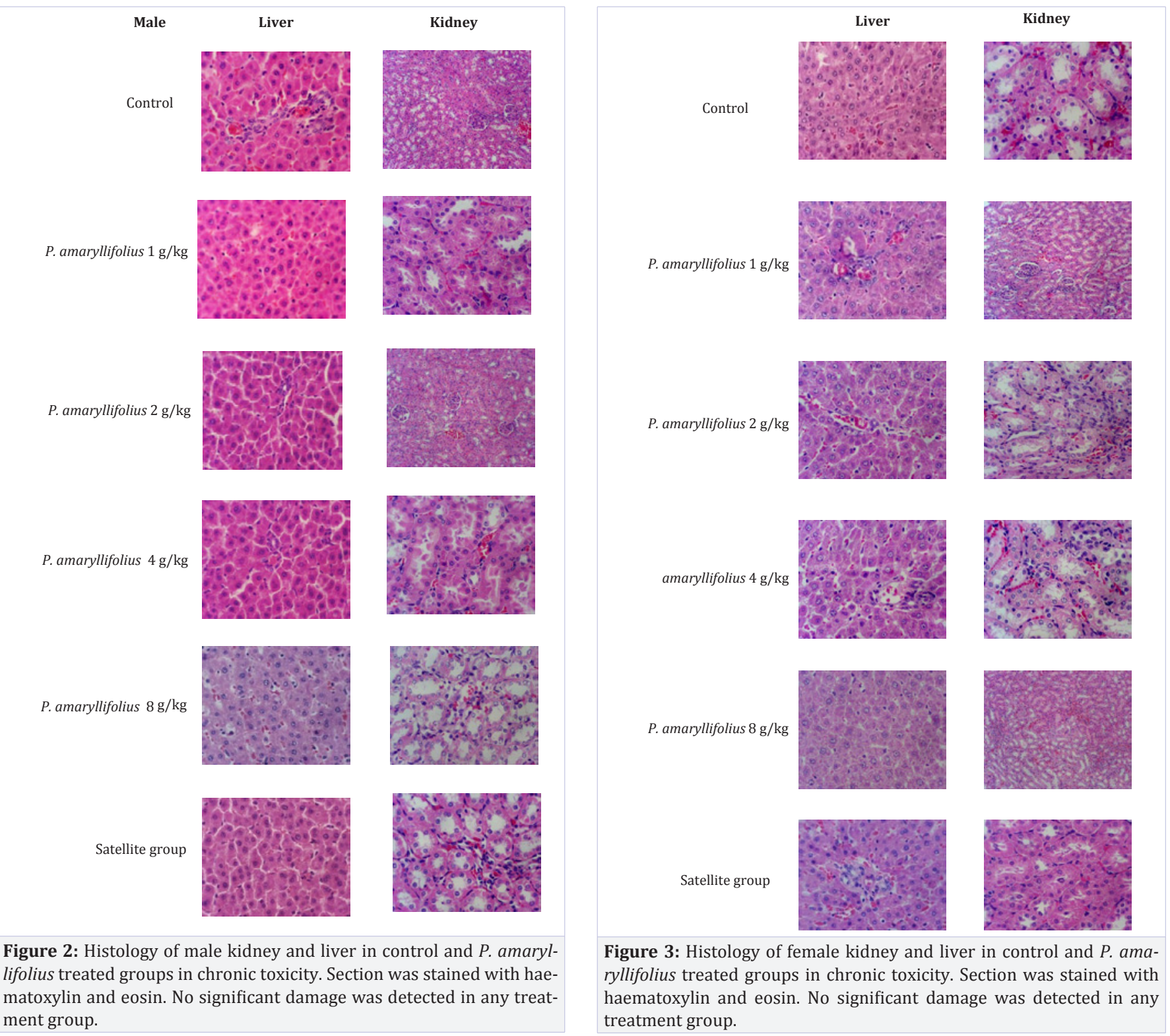

Citation: Sireeratawong S, Chiranthanut N, Lertprasertsuke N, Jaijoy K (2016) Acute and Chronic Toxicities of Pandanus Amaryllifolius Roxb. Water Extract from the Roots in Rats. SOJ Pharm Pharm Sci, 3(2), 1-7. DOI: http://dx.doi.org/10.15226/2374-6866/3/1/00140 
testis, epididymis, muscle and nerve, thoracic spine, eyes and brain were normal in both the control and the treated groups. In addition, histology of tissues showed no abnormality of liver and kidney as compared to the control group. Therefore, $P$. amaryllifolius extract does not produce chronic toxicity in liver and kidney (Fig. 2-3).

\section{Conclusion}

In conclusion, after analyzed and evaluated all factors in animals including symptoms, body weight, organ weight, histology and gross examination, hematologic and biochemistry of blood, we can assure that the water extract from the roots of $P$. amaryllifolius does not cause both oral acute and chronic toxicities in rats.

\section{Acknowledgements}

The authors are thankful to the Department for Development of Thai Traditional and Alternative Medicine Ministry of Public Health for financial support

\section{Declarations}

The authors have no conflict of interest to declare.s.

\section{References}

1. Sasidharan S, Sumathi V, Jegathambigai NR, Latha LY. Ant hyperglycaemic effects of ethanol extracts of Carica papaya and Pandanus amaryfollius eaf in streptozotocin-induced diabetic mice. Nat Prod Res. 2011;25(20):1982-1987.

2. Peungvicha P, Wongkrajang $\mathrm{Y}$, Ruangsomboon $\mathrm{O}$, Suvitayavat $\mathrm{W}$ Hypoglycemic effect of water extract of the root of Pandanus odorus II: in alloxan diabetic rats. J Pharm Sci. 1990;17:29-35.

3. Peungvicha P, Thirawarapan SS, Watanabe H. Hypoglycemic and hypolipidemic effect of the water extract of Pandanus odorus Ridl. Asia Pacific J Pharmacol. 1997;12:3-8.
4. Peungvicha $P$, Thirawarapan SS, Watanabe H. Hypoglycemic effect of water extract of the root of Pandanus odorus Ridl. Biol Pharm Bull. 1996;19(3):364-366.

5. Organization of Economic Co-operation and Development. The OECD guideline for testing of chemical: 420 Acute Oral Toxicity-Fixed Dose Method. Paris France; 2001.

6. World Health Organization (WHO). General guidelines for methodologieson research and evaluation of traditional medicine. EDM/TRM/2000.1.Switzerland; 2000.

7. Organization of Economic Co-operation and Development. The OECD guideline for testing of chemical: 452 Chronic Toxicity Studies. France; 2009.

8. Carol SA, Michael JD. Acute, Sub chronic and Chronic Toxicology. In CRC Handbook of Toxicology. Third edition. CRC Press. U.S.A. 1995 51104.

9. Feldman BV, Zinkl JG, Jain NC. Schalm's Veterinary Hematology. Fifth edition. Lea Febiger. Philadelphia. 2000.

10. National laboratory animal center. Hematological data of NLAC-MU laboratory animals. Mahidol University. Thailand. 2016.

11. Barry SL. Animal Clinical Pathology. In CRC Handbook of Toxicology. Michael JD, Mannfred AH (Ed). CRC Press. U.S.A. 1995;517-537.

12. National laboratory animal center. Clinical chemistry of NLAC-MU laboratory animals. Mahidol University. Thailand. 2016.

13. Sacher RA, McPherson RA. General chemistry. In Widmann's Clinica Interpretation of Laboratory Test, $10^{\text {th }}$ ed. F.A. Davis Company, U.S.A. 1991;318-365.

14. Sacher RA, McPherson RA. Test of liver function. In Widmann's Clinical Interpretation of Laboratory Test, $10^{\text {th }}$ ed. F.A. Davis Company, U.S.A. 1991;416-443.

15. Caisey JD, King DJ. Clinical chemical values for some common laboratory animals. Clin Chem. 1980;26(13):1877-1879. 